\title{
Implementasi Block Cipher Electronic Codebook (ECB) untuk Pengamanan Data Pegawai
}

\author{
Implementation Of Block Cipher Electronic Codebook (ECB) For Employee Data \\ Security
}

\author{
Wahyu Ariandi*1, Susi Widyastuti ${ }^{2}$, Lutfi Haris ${ }^{3}$ \\ 1,2,3 Program Studi Teknik Informatika, STIKOM Poltek Cirebon \\ e-mail: ${ }^{* 1}$ wahyuariandi@mail.ugm.ac.id, ${ }^{2}$ susi.widyastuti@ stikompoltek.ac.id, \\ ${ }^{3}$ luthfihazis28@gmail.com
}

\begin{abstract}
Abstrak
Data pegawai adalah satu data penting dan basic pada PDAM Tirta Sanita Sumber, dimana data ini akan terhubung keberbagai system seperti kenaikkan pangkat, penggajian, pelaporan dan tanggungjawab pekerjaan. Untuk melindungi kerahasiaan data pegawai dari orang-orang yang tidak berhak, maka pengelola system informasi dapat melakukan pengamanan data melalui Teknik kriptografi, pada penelitian ini peneliti menggunakan algoritma Electronic Codebook (ECB) untuk mengamankan data pegawai. Berdasarkan hasil penelitian didapatkan hasil bahwa algoritma ECB mampu melakukan enkripsi dan deskripsi data pegawai pada PDAM Tirta Sanita Sumber dengan baik, sehingga data pegawai dapat terlindungi dari orang-orang yang tidak berhak mengetahui. Melalui hasil uji pada 50 data pengujian, didapatkan ketepatan proses enkripsi dan deskripsi sebesar 96\%, hal ini didukung oleh tingkat prosentase kepuasan user terhadap kinerja enkripsi dan dekripsi aplikasi sebesar $82 \%$. Sedangkan dari sisi pengujian fungsionalitas keseluruhan aplikasi secara blackbox didapatkan bahwa aplikasi sudah maтри memenuhi segala kebutuhan fungsionalitasnya dengan prosentase sebesar 100\% benar
\end{abstract}

Kata kunci-Kriptografi, ECB, Blackbox, data pegawai

\begin{abstract}
One of the most important data in PDAM Tirta Sanita Sumber is employee data. This data will connected and associated with several part of organization system like employee promotion, salary, reporting, and job desk. To keep confidentiality of employee data from people who don't have access right, cryptography can be used for protecting this data. This research used Electronic Codebook (ECB) Algorithm to apply cryptography technique. This research found that ECB Algorithm can encrypt and decrypt employee data of PDAM Tirta Sanita Sumber. From testing process of 50 data, we discovered that this algorithm produced $96 \%$ accuracy of encryption and decryption process and $82 \%$ customer satisfaction from this algorithm performance. While, from black box testing to conduct test of system functionality, this system can satisfy customer needs with 100\% success.
\end{abstract}

Keywords-3-5 keywords, Algorithm A, B algorithms, complexity

\section{PENDAHULUAN}

Masalah keamanan merupakan salah satu aspek penting dari suatu sistem, namun sayangnya masalah keamanan ini masih kurang mendapat perhatian khusus dari para pemilik dan pengelola system informasi. Saat ini semua pengolahan data pada Perusahaan Daerah Air Minum (PDAM) Tirta Jati Sumber, Kabupaten Cirebon sudah terkomputerisasi dengan baik dan saling berhubungan satu sama lain ke setiap divisinya. Salah satunya adalah system kenaikkan pangkat, system penggajian, system pelaporan dan system pelayanan yang semuanya terhubung dengan data pegawai yang ada di database perusahaan. Berdasarkan hal tersebut, maka dapat dikatakan bahwa data pegawai merupakan data basic dari PDAM Tirta Jati, dan memiliki

Informasi Artikel:

Submitted: Juni 2020, Accepted: Juli 2020, Published: November 2020

ISSN: 2685-4902 (media online), Website: http://jurnal.umus.ac.id/index.php/intech 
peranan yang sangat penting. Dengan mengetahui nama seseorang dari data pegawai, maka orang lain dapat dengan mudahnya mengetahui informasi mengenai jabatan, gaji, tanggungjawab ataupun pekerjaan yang dilakukan oleh pegawai tersebut. Untuk melindungi kerahasiaan data pegawai dari orang-orang yang tidak berhak tersebut, maka pengelola system informasi dapat melakukan pengamanan data melalui teknik kriptografi yang akan menyamarkan data asli perusahaan menjadi data-data yang telah terenkripsi[1]. Melihat beberapa analisis permasalahan diatas, maka penelitian ini bertujuan untuk mengetahui penerapan algoritma Electronic Codebook (ECB) untuk mengamankan data pegawai pada PDAM Tirta Jati Sumber.

Berbagai teknik pengamanan data yang pernah dilakukan melalui pendekatan kriptografi beberapa diantaranya adalah pada penerapan algoritma XOR untuk mengamankan data guru pada sekolahan XYZ[2], algoritma DES yang digunakan untuk mengamankan data karyawan di CV. Sinergi Informasi Global [3], algoritma MD5 utk pengolahan data pada bagian tatausaha Lembaga Sandi Negara [4], algoritma AES untuk pengamanan data gaji karyawan di PT Capella Medan [5], serta kombinasi antara algoritma caesar chipper dan vigenere cipher untuk mengekripsi dan dekripsi data penggajian di PT. Kemasindo Cepat Nusantara [6]. Kombinasi antara Diffie - Hellman, Message-Digest 5 dan Rivest Chiper 4 juga akan menghasilkan kekuatan yang jauh lebih baik untuk proses enkripsi dan dekripsi[7]. Pengamanan data pesesrta juga pernah dilakukan dengan menggunakan AES [8]

Berbeda dengan beberapa algoritma diatas, pada penelitian ini peneliti menggunakan algoritma Electronic Codebook (ECB) untuk mengamankan data pegawai pada PDAM Tirta Jati Sumber, algoritma Electronic Codebook (ECB) dipilih karena data pegawai yang akan dienkripsi bersifat acak dan hal ini memungkinkan blok plaintext akan dienkripsi secara independen[9]. Beberapa penelitian mengenai penerapan ECB juga pernah dilakukan dengan membandingkan antara waktu enkripsi yang dihasilkan oleh ECB dan CBC pada optimasi blowfish, dan hasil penelitiannya menunjukkan bahwa optimasi blowfish dengan ECB mampu melakukan enkripsi lebih cepat dari pada CBC[10]. ECB juga pernah dikombinasikan dengan vigenere chipher untuk proses pengamanan data, dimana hasilnya dapat lebih bagus tetapi memerlukan waktu yang lebih lama baik dalam mengenkripsi maupun dekripsi plainteks[11].

\section{METODE PENELITIAN}

Pada penelitian ini penulis menggunakan pendekatan secara RUP (Rational Unified Process) karena mampu memenuhi semua kebutuhan pihak-pihak yang berkepentingan[12]. Pendekatan RUP memiliki 4 fase dalam pendefinisiannya yaitu insepsi (akan menghasilkan analisis kebutuhan), elaborasi (menghasilkan perancangan), konstruksi (implementasi dan testing system), transaksi (pengujian)[13].

Penelitian ini akan dimulai dengan studi literatur mengenai berbagai macam algoritma enkripsi yang memiliki kekuatan agar tidak dengan mudah di ketahui, dari tahap studi literatur penulis memutuskan untuk menggunakan ECB sebagai algoritma yang akan digunakan, kemudian akan dilakukan pengumpulan data dimana tahapan ini merupakan mencari data basic yang ada di PDAM Tirta Jati Sumber yang akan menjadi fokus enkripsi. Langkah selanjutnya yaitu masuk kedalam proses RUP, pada tahap insepsi peneliti akan menganalisa proses bisnis seperti alur penggunaan data pegawai pada PDAM Tirta Jati akan digunakan untuk proses apa saja, dan hal ini terlihat bahwa data pegawai digunakan pada proses pengolahan data penggajian, kenaikan pangkat, tanggungjawab pekerjaan, dan pelaporan. Semua kebutuhan yang didapatkan pada tahap insepsi selanjutnya digambarkan dalam bentuk usecase dan activity diagram. Setelah semua kebutuhan input didapatkan maka langkah selanjutnya yaitu dilakukan perancangan secara squance diagram, GUI, dan penerapan ECB terhadap data pegawai. Pada tahap kontruksi penulis akan mengimplementasikan perancangan menjadi suatu aplikasi kemudian mengujinya melalui validation testing. Dan pada tahap akhir RUP akan dilakukan 
kembali proses pengujian secara UAT pada tahap transisi. Rangkuman mengenai tahapan yang dilakukan pada RUP tergambar pada Gambar 1.

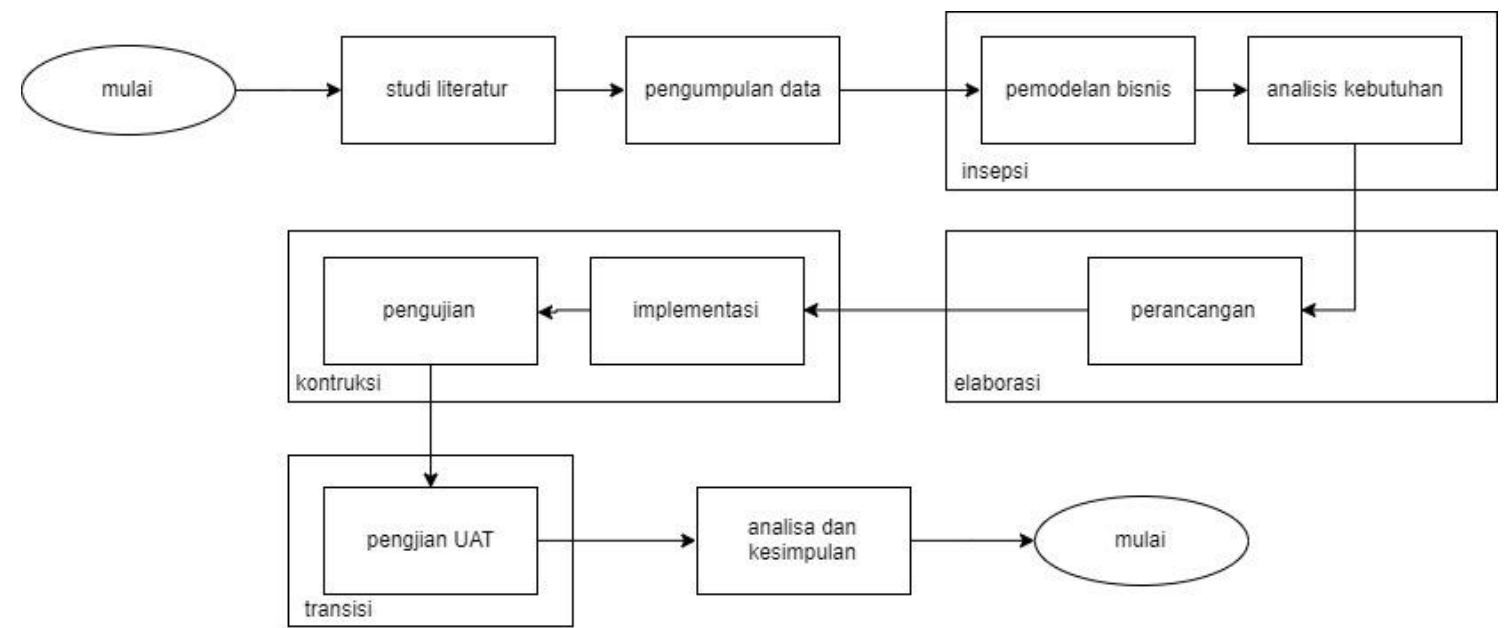

Gambar 1. Alur RUP pada penelitian

\section{Electronic Codebook (ECB)}

Electronic codebook (ECB) merupakan salah satu mode operasi yang setiap karakteristik nilai plaintext nya memiliki nilai yang sama seperti ciphertext[10]. Secara matematis dapat dinyatakan dengan[14] :

$$
\begin{aligned}
& C_{i}=E_{k}\left(P_{i}\right) \\
& P_{i}=D_{k}\left(C_{i}\right)
\end{aligned}
$$

Adapun proses enkripsinya adalah:

1. Ubah plaintext menjadi kode ASCII

2. Ubah hasil no 1 menjadi bentuk bilangan biner 8 bit

3. Ubah key dalam bentuk biner

4. Kombinasikan plaintext dengan key

5. Konversikan dalam bentuk decimal

6. Ubah hasil no 5 menjadi cipertext

Sedangkan proses untuk dekripsinya adalah

1. Ubah cipertext menjadi bilangan biner

2. Ubah bilangan decimal menjadi bilangan biner atau xor dengan kunci

3. Ubah xor biner menjadi bilangan decimal

4. Didapatkan plaintext

\section{HASIL DAN PEMBAHASAN}

\section{Insepsi}

Berdasarkan Gambar 1, maka pada tahap insepsi akan didapatkan analisa terhadap kebutuhan yang diperlukan serta pemodelan yang cocok, yang selanjutnya akan digambarkan menjadi usecase dan activity diagram. Adapun desain prosedur untuk enkripsi dan dekripsi yang dilakukan adalah sebagai berikut:

1. Untuk dapat melakukan enkripsi dan deskripsi data pegawai, user harus melakukan login terlebih dahulu dengan memasukan username dan password yang sudah tervalidasi. 
2. Setelah berhasil melakukan login, user dapat melakukan enkripsi atau deskripsi file pegawai.

3. Untuk melakukan enkripsi maupun dekripsi user harus mengisi terlebih dahulu data-data pegawai kedalam aplikasi.

4. Kemudian data akan di enkripsi dan deskripsi oleh database ke dalam aplikasi.

5. Setelah data terenkripsi dan terdeskripsi data akan tersimpan kedalam database.

Gambaran mengenai usecase diagram dan activity diagram tersebut terlihat pada Gambar 1 dan 2.

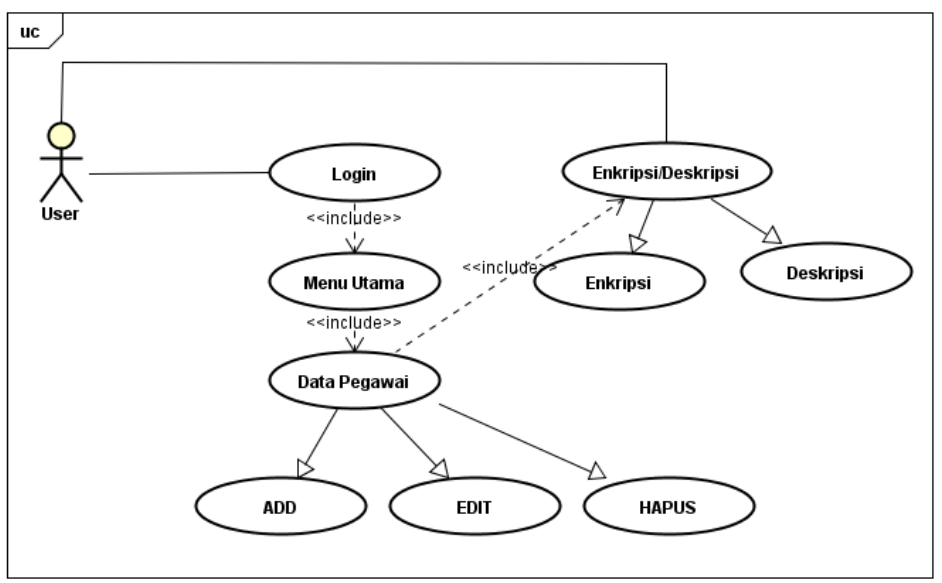

Gambar 1. Usecase diagram

Actor yang terlibat pada aplikasi adalah para pegawai yang login keaplikasi, dimana pegawai ini hanya dapat melakukan perubahan ataupun penghapusan data dirinya. Untuk activity diagram yang terbentuk berdasarkan Gambar 1 adalah 6 buah activity diagram diantaranya adalah activity login, activity menu input, activity menu edit, activity menu hapus, activity enkripsi, activity deskripsi. Gambar 2 merupakan activity diagram untuk enkripsi yang dilakukan oleh aplikasi.

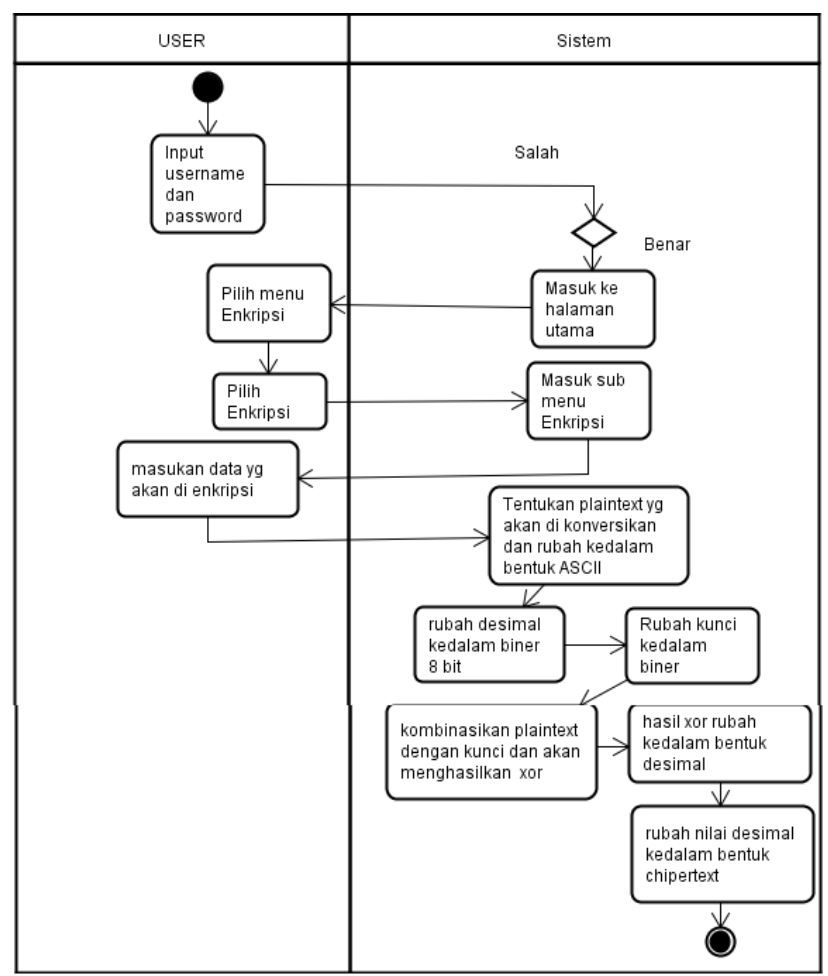

Gambar 2. Activity diagram enkripsi 


\section{Elaborasi}

Pada penelitian ini, penulis akan menggunakan data pegawai sebagai fokus enkripsi dan dekripsi kerahasiaan data yang akan dilakukan. Pada tahapan ini akan dilakukan penerapan algoritma ECB terhadap data pegawai seperti berikut:

\section{Enkripsi Block Chipper} berikut:

Sedangkan untuk prosedur enkripsi block chipper yang dilakukan adalah sebagai

1. Langkah pertama pada tahap ini mengubah pesan atau plaintext di konversikan dengan cara konversi menggunakan kode ASCII. Tabel 1 adalah bentuk konversi plaintext LUTFI kedalam kode ASCII.

Table 1. Konversi plaintext kedalam ASCII

\begin{tabular}{cccccc}
\hline Plaintext & L & U & T & F & I \\
\hline Desimal & 76 & 85 & 84 & 70 & 73 \\
\hline
\end{tabular}

2. Setelah mendapatkan hasil bilangan decimal dari plainteks selanjutnya akan mengubah bilangan ke decimal kedalam bentuk biner 8 bit dengan cara:

a. Buatlah deret bilangan 2 pangkat yang dimulai dari $2^{\circ}$. Penulisan dimulai dari sebelah kanan. Batas bilangan harus kurang dari atau sama dengan $(<=)$ nilai ASCII. Pada nilai

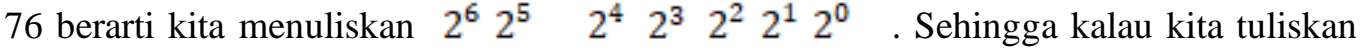
jumlah perpangkatannya, akan kita temukan bilangan, Sehingga kalau kita tuliskan jumlah perpangkatannya, akan kita temukan bilangan 64, 32, 16, 8, 4, 2, 1

b. Kemudian kurangi 76 dengan 64 . Karena 76 bisa dikurangi dengan 64 maka kita tuliskan $1.76-64=12$. Kemudian hasil 12 dikurangkan dengan 32. Karena 12 tidak bisa dikurangi dengan 32, maka kita tuliskan 0. Kemudian $9-16$. Dan karena tidak bisa lagi kita tuliskan 0. Dan begitulah seterusnya sampai 1 sehingga dari nilai 76 akan terbentuk bilangan 1001100. Karena hanya ada 7 bilangan maka kita tambahkan 0 di depan menjadi 01001100. Sehingga kita sudah menemukan biner 8 bit dari L. Lakukan hal yang sama untuk mencari binner 8 bit dari teks selanjutnya UTFI. Hasil perubahan ini terdapat pada Tabel 2.

Table 2. konversi ASCII kedalam biner 8 bit

\begin{tabular}{cccccc}
\hline ASCII & 76 & 85 & 84 & 70 & 73 \\
\hline Biner 8 bit & 01001100 & 01010101 & 01010100 & 01000110 & 01001001 \\
\hline
\end{tabular}

3. Pada tahap ini melakukan perubahan key atau kunci kedalam bentuk biner. Kunci yang akan digunakan adalah YOxKa, hasil perubahan key menjadi biner terdapat pada Tabel 3.

Table 3. Konversi key menjadi biner

\begin{tabular}{cccccc}
\hline Kunci & Y & O & X & K & a \\
\hline Biner & 01111001 & 01101111 & 01111000 & 01101011 & 01100001 \\
\hline
\end{tabular}

4. Langkah selanjutnya pada tahap ini dilakukan kombinasi Antara plaintext dengan kunci. Hasil kombinasi antara plaintext dengan key terdapat pada Tabel 4

Table 4. Hasil kombinasi plaintext dengan kunci

\begin{tabular}{cccccc}
\hline Plaintext & 01001100 & 01001100 & 01010100 & 01000110 & 01001001 \\
\hline Key & 01111001 & 01101111 & 01111000 & 01101011 & 01100001 \\
\hline XOR & 00110101 & 00100011 & 00101100 & 00101101 & 00101000 \\
\hline
\end{tabular}

5. Tahap kelima pada tahap ini hasil yang sudah di dapat di konversikan kedalam bentuk desimal. Table 5 merupakan hasil konversi poin 4 menjadi desimal. 
Table 5. Hasil konversi XOR ke desimal

\begin{tabular}{cccccc}
\hline XOR & 00110101 & 00100011 & 00101100 & 00101101 & 00101000 \\
\hline Decimal & 53 & 58 & 44 & 45 & 40 \\
\hline
\end{tabular}

6. Tahap terakhir ubah nilai decimal kedalam chipertext. Hasil perubahan decimal kedalam chipertext terdapat pada Tabel 6.

Table 6. Hasil konversi decimal menjadi chipertext

\begin{tabular}{llllll}
\hline Decimal & 53 & 58 & 44 & 45 & 40 \\
\hline Chipertext & 5 & $:$ &, & - & ( \\
\hline
\end{tabular}

\section{Prosedur Deskripsi Block Cipher Mode ECB}

1. Langkah pertama proses deskripsi, pada tahap ini hasil yang sudah di dapatkan chipertext lalu di konversikan kedalam biner. Hasil konversi ini terdapat pada Tabel 7.

Table 7. Konversi chipertext kedalam biner

\begin{tabular}{llllll}
\hline CHIPERTEXT & 5 & $:$ &, & - & ( \\
\hline Decimal & 53 & 58 & 44 & 45 & 40 \\
\hline
\end{tabular}

2. Langkah selanjutnya ubah bilangan decimal menjadi bilangan biner dan xor dengan kunci. Hasil konversi ini terdapat pada Tabel 8.

Tabel 8. Hasil konversi chipertext dengan kunci

\begin{tabular}{llllll}
\hline Chipertext & 00110101 & 00111010 & 00101100 & 00101101 & 00101000 \\
\hline Kunci & 01111001 & 01101111 & 01111000 & 01101011 & 01100001 \\
\hline Xor & 01001100 & 01010101 & 01010100 & 01000110 & 01001001 \\
\hline
\end{tabular}

3. Ubah hasil xor biner menjadi bilangan decimal. Hasil konversi xor menjadi decimal terdapat pada Tabel 9.

Table 9. Hasil konversi chipertext ke desimal

\begin{tabular}{llllll}
\hline $\begin{array}{l}\text { Chipertext } \\
\text { biner }\end{array}$ & 01001100 & 01010101 & 01010100 & 01000110 & 01001001 \\
\hline Desimal & 76 & 85 & 84 & 70 & 73 \\
\hline
\end{tabular}

4. Tahap terakhir sudah menjadi karakter. Hasilnya adalah pada Tabel 10.

Table 10. Hasil dekripsi

\begin{tabular}{lllll}
\hline $\mathrm{L}$ & $\mathrm{U}$ & $\mathrm{T}$ & $\mathrm{F}$ & $\mathrm{I}$ \\
\hline
\end{tabular}

\section{Konstruksi}

Pada tahap ini akan dilakukan pengimplementasian perancangan algoritma ECB menjadi suatu aplikasi. Gambar 3 dan 4 merupakan tampilan untuk enkripsi dan dekripsi yang dihasilkan. 


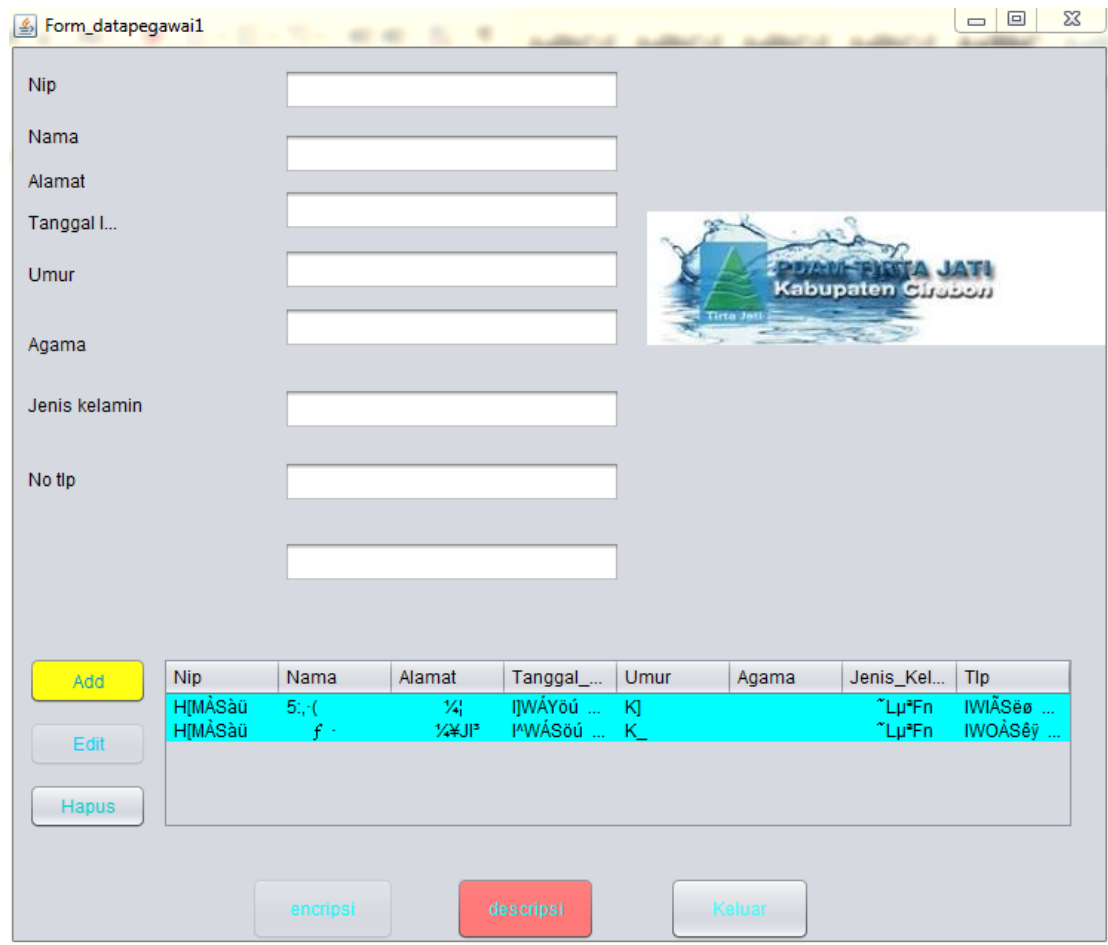

Gambar 2. Tampilan Menu Utama Deskripsi

Berdasarkan Gambar 2 button enkripsi berfungsi untuk mengenkripsi data, untuk mengenkripsi data pilih button enkripsi maka data pada database akan otomatis terenkripsi data tidak dapat diedit. Sedangkan pada Gambar 3 button deskripsi untuk mengdeskripsi data, untuk mengdeskripsi data pilih button deskripsi maka data pada database akan otomatis terdeskripsi dan button deskripsi akan di non aktifkan.

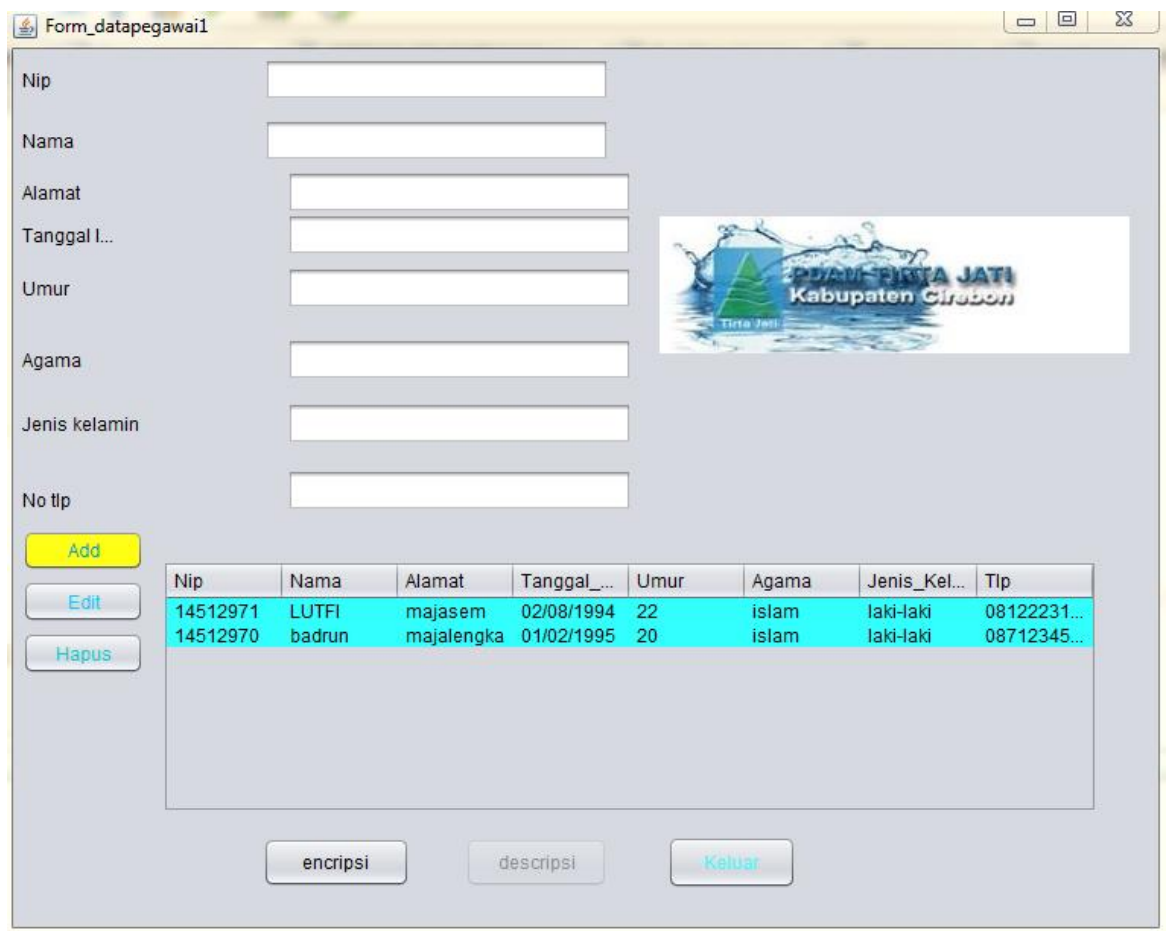

Gambar 3. Tampilan Menu Utama Deskripsi 
Aplikasi yang dibangun memiliki 6 form yaitu form login, tambah data pegawai, edit data pegawai, hapus data pegawai, enkripsi, deskripsi. Untuk memastikan bahwa semua form tersebut sudah bekerja dengan baik sesuai fungsionalitasnya maka akan dilakukan pengujian menggunakan blackbox. Hasil pengujian tersebut terangkum pada Tabel 11.

Table 11. Hasil pengujian blackbox

\begin{tabular}{|c|c|c|c|c|c|}
\hline No & $\begin{array}{c}\text { Jenis } \\
\text { Pengujian }\end{array}$ & Deskripsi & $\begin{array}{c}\text { Hasil Yang } \\
\text { Diharapkan }\end{array}$ & Hasil pengamatan & Kesimpulan \\
\hline 1 & Form login & $\begin{array}{l}\text { User memasukkan } \\
\text { username dan } \\
\text { password benar }\end{array}$ & $\begin{array}{l}\text { Pengecekkan } \\
\text { kedalam database, } \\
\text { dan system berhasil } \\
\text { membawa user ke } \\
\text { halaman pegawai }\end{array}$ & $\begin{array}{l}\text { Database berhasil } \\
\text { mengenali username } \\
\text { dan password dan } \\
\text { membawa user } \\
\text { kehalaman pegawai }\end{array}$ & Sesuai \\
\hline 2 & Form login & $\begin{array}{l}\text { User memasukkan } \\
\text { username dan } \\
\text { password salah }\end{array}$ & $\begin{array}{l}\text { Pengecekkan } \\
\text { kedalam database, } \\
\text { dan system akan } \\
\text { menolah username } \\
\text { yang dimasukkan }\end{array}$ & $\begin{array}{lr}\text { Database } & \text { berhasil } \\
\text { tidak } & \text { mengenali } \\
\text { username } & \text { dan } \\
\text { password } & \text { dan } \\
\text { menampilkan pesan }\end{array}$ & Sesuai \\
\hline 3 & $\begin{array}{l}\text { Edit data } \\
\text { pegawai }\end{array}$ & $\begin{array}{l}\text { User memasukkan } \\
\text { data nama pegawai } \\
\text { yang akan diedit }\end{array}$ & $\begin{array}{lr}\text { Aplikasi akan } \\
\text { mengecek ejaan nama } \\
\text { pegawai yang diedit } \\
\text { jika huruf semua } \\
\text { maka data akan } \\
\text { disimpan dalam table }\end{array}$ & $\begin{array}{lr}\text { Aplikasi berhasil } \\
\text { menyimpan data } \\
\text { pegawai yang } \\
\text { namanya dirubah }\end{array}$ & Sesuai \\
\hline 4 & $\begin{array}{l}\text { Edit data } \\
\text { pegawai }\end{array}$ & $\begin{array}{l}\text { User memasukkan } \\
\text { data nama pegawai } \\
\text { dengan kombinasi } \\
\text { huruf dan angka }\end{array}$ & $\begin{array}{lr}\text { Aplikasi } & \text { akan } \\
\text { menampilkan } & \text { pesan } \\
\text { bahwa nama pegawai } \\
\text { tidak } \\
\text { kombinasi boleh } \\
\text { huruf dan angka } \\
\end{array}$ & $\begin{array}{l}\text { Aplikasi } \\
\text { menampilkan pesan }\end{array}$ & Sesuai \\
\hline 5 & $\begin{array}{l}\text { Hapus data } \\
\text { pegawai }\end{array}$ & $\begin{array}{l}\text { User akan } \\
\text { menghapus salah satu } \\
\text { nama pegawai } \\
\text { berdasarkan id / nama } \\
\text { pegawai tersebut }\end{array}$ & $\begin{array}{l}\text { Aplikasi } \\
\text { menampilkan pesan } \\
\text { dan jika user } \\
\text { mengklik button } \\
\text { hapus maka data akan } \\
\text { terhapus dari table }\end{array}$ & $\begin{array}{l}\text { Aplikasi berhasil } \\
\text { menampilkan pesan } \\
\text { konfirmasi dan data } \\
\text { terhapus dari table }\end{array}$ & Sesuai \\
\hline 6 & Enkripsi & $\begin{array}{l}\text { User akan mengklik } \\
\text { button enkripsi data } \\
\text { pegawai yang akan } \\
\text { diamankan }\end{array}$ & $\begin{array}{l}\text { Aplikasi akan } \\
\text { melakukan enkripsi } \\
\text { dan menampilkan } \\
\text { hasil enkripsinya } \\
\text { pada gridview }\end{array}$ & $\begin{array}{ll}\text { Aplikasi } & \\
\text { menampilkan } & \text { hasil } \\
\text { enkripsi } & \text { pada } \\
\text { gridview } & \end{array}$ & Sesuai \\
\hline 7 & Dekripsi & $\begin{array}{l}\text { User akan mengklik } \\
\text { button deskripsi data } \\
\text { pegawai yang akan } \\
\text { diamankan }\end{array}$ & $\begin{array}{lr}\text { Aplikasi } & \text { akan } \\
\text { melakukan } & \text { deskripsi } \\
\text { dan } & \text { menampilkan } \\
\text { hasil } & \text { dekripsinya } \\
\text { pada text field } \\
\text { pegawai }\end{array}$ & $\begin{array}{l}\text { Aplikasi } \\
\text { menampilkan } \\
\text { deskripsi } \\
\text { textfiled }\end{array}$ & Sesuai \\
\hline
\end{tabular}
bahwa:

Sedangkan untuk tingkat kesalahan dari 50 uji coba data pegawai didapatkan hasil

$$
\begin{aligned}
\text { hasil pengujian } & =\frac{j u m l a h \text { benar }}{\text { jumlah data }} \times 100 \% \\
\text { hasil pengujian } & =\frac{48}{50} \times 100 \% \\
\text { hasil pengujian } & =96 \%
\end{aligned}
$$




\section{Transisi}

Pada tahap pengujian UAT, penulis akan menyediakan jawaban terhadap pertanyaan-pertanyaan yang akan dijawab oleh responden, rangkuman mengenai jawaban tersebut terangkum pada Tabel 12.

Tabel 12. Pilihan jawaban

\begin{tabular}{|c|l|}
\hline Nilai & \multicolumn{1}{c|}{ Keterangan } \\
\hline A & Sangat : mudah / bagus / sesuai / jelas \\
\hline B & Mudah / bagus / sesuai / jelas \\
\hline C & Netral \\
\hline D & Cukup : sulit / bagus / sesuai / jelas \\
\hline E & Sangat : sulit / jelek / tidak sesuai / tidak jelas \\
\hline
\end{tabular}

Sedangkan untuk bobot dari masing-masing jawaban yang akan dijawab terangkum pada Tabel 13.

Table 13. Bobot jawaban

\begin{tabular}{|l|l|}
\hline \multicolumn{1}{|c|}{ Jawaban } & Bobot \\
\hline A: Sangat : mudah / bagus / sesuai / jelas & 5 \\
\hline B: Mudah / bagus / sesuai / jelas & 4 \\
\hline C: Netral & 3 \\
\hline D: Cukup : sulit / bagus / sesuai / jelas & 2 \\
\hline E: Sangat : sulit / jelek / tidak sesuai / tidak jelas & 1 \\
\hline
\end{tabular}

Sedangkan daftar pertanyaan dan hasil respon user untuk pertanyaan-pertanyaan yang diajukan terangkum pada Tabel 14 .

Tabel 14. Hasil respon user

\begin{tabular}{|c|l|c|c|c|c|c|}
\hline \multirow{2}{*}{ No } & \multicolumn{1}{|c|}{ Pertanyaan } & \multicolumn{3}{c|}{ Nilai } & \multirow{2}{*}{ Jumlah } \\
\cline { 2 - 5 } & \multicolumn{1}{|c|}{ A } & B & C & D & \\
\hline 1 & $\begin{array}{l}\text { apakah tampilan dari aplikasi ini } \\
\text { mudah dipahami? }\end{array}$ & 40 & 24 & 6 & 2 & 72 \\
\hline 2 & $\begin{array}{l}\text { apakah kombinasi warna pada } \\
\text { aplikasi sudah sesuai? }\end{array}$ & 2 & 0 & 20 & 15 & 37 \\
\hline 3 & $\begin{array}{l}\text { apakah tombol-tombol pada aplikasi } \\
\text { ini mudah dipahami }\end{array}$ & 35 & 22 & 12 & 0 & 69 \\
\hline 4 & $\begin{array}{l}\text { apakah hasil enkripsi membantu } \\
\text { mengamankan data }\end{array}$ & 40 & 20 & 10 & 1 & 71 \\
\hline 5 & $\begin{array}{l}\text { apakah hasil dekripsi sama dengan } \\
\text { plaintext }\end{array}$ & 40 & 20 & 0 & 0 & 60 \\
\hline
\end{tabular}

Berdasarkan Tabel 14, diketahui bahwa untuk pertanyaan pertama prosentase kepuasan user dari tampilan aplikasi masih rendah yaitu hanyalah $71 \%$, pengaturan warna dan tataletak tombol juga juga sekitar $72 \%$, namun user merasa puas terhadap proses enrkipsi dan dekripsi data yang dilakukan oleh aplikasi yaitu yang mencapai $82 \%$.

\section{KESIMPULAN}

Berdasarkan hasil penelitian didapatkan hasil bahwa algoritma ECB mampu melakukan enkripsi dan deskripsi data pegawai pada PDAM Tirta Sanita Sumber dengan baik, sehingga data pegawai dapat terlindungi dari orang-orang yang tidak berhak mengetahui. Melalui hasil uji pada 50 data pengujian, didapatkan ketepatan proses enkripsi dan deskripsi sebesar $96 \%$, hal ini didukung oleh tingkat prosentase kepuasan user terhadap kinerja enkripsi dan dekripsi aplikasi sebesar $82 \%$. Sedangkan dari sisi pengujian fungsionalitas keseluruhan aplikasi secara blackbox 
didapatkan bahwa aplikasi sudah mampu memenuhi segala kebutuhan fungsionalitasnya dengan prosentase sebesar $100 \%$ benar.

\section{DAFTAR PUSTAKA}

[1] R. Aulia, A. Zakir, and D. A. Purwanto, "Penerapan Kombinasi Algoritma Base64 Dan Rot47 Untuk Enkripsi Database Pasien Rumah Sakit Jiwa Prof. Dr. Muhammad Ildrem," InfoTekJar (Jurnal Nas. Inform. dan Teknol. Jaringan), vol. 2, no. 2, pp. 146-151, 2018, doi: 10.30743/infotekjar.v2i2.300.

[2] A. A and D. Dasril, "Perancangan Aplikasi Pengamanan Data Menggunakan Algoritma XOR," J. IT, vol. 8, no. 1, pp. 61-69, 2017.

[3] S. Hanadwiputra, "Implementasi Enkripsi Dalam Pengamanan File Data Karyawan Dengan Metode Algoritma DES (Data Encryption Standard) Pada CV. Sinergi Informasi Global," J. Gema Kampus, vol. 13, no. 2, pp. 61-69, 2018.

[4] N. KUSTIAN, "Sistem Informasi Pengamanan Basis Data Menggunakan Teknik Enkripsi Bagian Tata Usaha Lembaga Sandi Negara," Fakt. Exacta, vol. 7, no. 2, pp. 188-199, 2015, doi: 10.30998/FAKTOREXACTA.V7I2.259.

[5] J. Prayudha, S. Saniman, and I. Ishak, "Implementasi Keamanan Data Gaji Karyawan Pada PT . Capella Medan Menggunakan Metode Advanced Encryption Standard ( AES )," Sains dan Komput., vol. 18, no. 2, 2019.

[6] I. A. Susanto and A. Solichin, "Enkripsi Data Penggajian Dengan Algoritma Caesar Cipher dan Vigenere Cipher Pada PT. Kemasindo Cepet Nusantara," Skainika, vol. 1, no. 1, pp. 399-404, 2018.

[7] S. F. Rodiasyah, T. Wahyuni, and D. Sukmana, "Kombinasi Kriptografi Diffie-Hillman, Message-Digest 5 dan Rivest Chiper 4," J. Ilm. Intech Informatioan Technol. J. UMUS, vol. 2, no. 01, pp. 1-10, 2020, doi: https://doi.org/10.46772/intech.v2i01.180.

[8] S. Widyastuti, W. Ariandi, and V. Sulistiono, "Implementasi Kriptograsi Aes Dalam Pengamanan Data Seleksi Peserta Jamkesmas," J. Ilm. Intech Informatioan Technol. J. UMUS, vol. 1, no. 02, 2019, doi: https://doi.org/10.46772/intech.v1i02.66.

[9] A. P. Sidik and N. Mayasari, "Rancangan Model Algoritma Hybrid Teknik Enkripsi Xor Dengan Kombinasi Mode Block Cipher CBC - ECB 512 Bits dan Algoritme RSA," J. Tek. dan Inform., vol. 6, no. 2, 2019.

[10] I. A. W. Arnawa, P. E. W. C, and A. A. G. B. Putra, "Perbandingan Waktu Enkripsi Antara Metode Electronic Codebook (ECB) dan Chipher Block Chaining (CBC) Dalam Algoritma Blowfish," J. Ilmu Komput. Indones., vol. 5, no. 1, pp. 50-54, 2020, doi: https://doi.org/10.23887/jik.v5i1.3056.

[11] A. Widarma, H. F. Siregar, and M. D. Irawan, "Teknik Keamanan Data Menggunakan Vigenere Cipher Dan Electronic Code Book (ECB)," J-SAKTI (Jurnal Sains Komput. dan Inform., vol. 3, no. 2, p. 393, 2019, doi: 10.30645/j-sakti.v3i2.157.

[12] D. J. Hutahaean, N. H. Wardani, and W. Purnomo, "Pengembangan Sistem Informasi Penyewaan Gedung Berbasis Web dengan Metode Rational Unified Process (RUP) (Studi Kasus: Wisma Rata Medan)," J. Pengemb. Teknol. Inf. dan Ilmu Komput., vol. 3, no. Vol. 3, No. 6, Juni, pp. 5789-5798, 2019.

[13] F. Mubarok, H. Harliana, and I. Hadijah, "Perbandingan Antara Metode RUP dan Prototype Dalam Aplikasi Penerimaan Siswa Baru Berbasis Web," Creat. Inf. Technol. J. (CITEC JOURNAL), vol. 2, no. 2, pp. 114-127, 2015, doi: https://doi.org/10.24076/citec.2015v2i2.42.

[14] F. Zuli and A. Irawan, "Implementasi Kriptografi Dengan Algoritma Blowfish Dan Riverst Shamir Adleman (Rsa) Untuk Proteksi File," J. Ilm. FIFO, vol. 9, no. 1, p. 5, 2017, doi: 10.22441/fifo.v9i1.1437. 